The University of Southern Mississippi The Aquila Digital Community

Faculty Publications

3-1-1996

\title{
Community and the Economy: The Theory of Public Cooperation - Boswell,J
}

Mark A. Klinedinst

University of Southern Mississippi, M.Klinedinst@usm.edu

Follow this and additional works at: http://aquila.usm.edu/fac_pubs

Part of the Political Science Commons

\section{Recommended Citation}

Klinedinst, M. A. (1996). Community and the Economy: The Theory of Public Cooperation - Boswell,J. Journal of Economic Issues, 30(1), 341-342.

Available at: http://aquila.usm.edu/fac_pubs/5554

This Book Review is brought to you for free and open access by The Aquila Digital Community. It has been accepted for inclusion in Faculty Publications by an authorized administrator of The Aquila Digital Community. For more information, please contact Joshua.Cromwell@usm.edu. 
COMMUNITY AND THE ECONOMY: THE THEORY OF PUBLIC COOPERATION. By Jonathan Boswell. London: Routledge Publishing Company, 1994. Pp. 226.

I enjoyed reading this book. Jonathan Boswell addresses some of the most timely questions of our age with broad philosophical and empirical research. It is a book meant for a wide audience. The most appropriate use in colleges is probably at the upper-undergraduate or graduate level.

The goal of the good society, as Boswell sees it, is to be democratic communitarian. Democratic communitarianism is probably the goal of many economists who read the $J E I$ and others who want something more humane than the economy that develops from a society focused on the machinations of "autonomous individuals." Development of a society that explicitly promotes humans as individuals and as part of a human community is, for many, a worthy goal. Boswell identifies community as a means, and as an end as well.

$\mathrm{He}$ identifies the pillars of a modern economy as being both competitive markets and state economic activity. Interest groups with expansive representation across the economy and society act as a bridge between these two pillars. The experience of Austria's tripartite type of organization of the economy is given as an example (actually more than three interest groups should be represented in these bridging organizations). Other moderately successful attempts can be found in different periods in Sweden, the Netherlands, and Belgium. This book attempts to create a plan for a democratically oriented economy that is much more than just a "middle" or "third way." The complementareity of public cooperative organizations to market and state economic activity is seen as crucial in preventing a whole series of economic problems such as stagflation, environmental degradation, and the creation of an underclass. Societies organized along the lines described as democratic communitarian would be much more successful in the long run but possibly not in the short run.

Covering such a broad topic as the appropriate form of public cooperation in the economy across a wide range of countries is a difficult task, and one not likely to lead to highly specific steps that are always applicable. Boswell does take on this task without losing an appreciation for the difficulties of making these suggestions concrete. He highly recommends an attention to fraternity, associativeness, and participation for creating this humane economy. Priorities include the continuity of individuals and institutions, village-sized organizations, a massive extension of statutory disclosure, improved social monitoring, greatly extended networks for social mixing, forums for a wide range of social actors, supportive symbols and celebrations, and educational norms and exemplars of a cooperative nature. Creating the necessary conditions for this system would mean placing a stress on "education, anti-poverty, investment and publicly responsible enterprise: a parallel emphasis on 
communal schooling and health, and on local community; a thrust towards the wider mixing of social classes and networks for participation."

His prognosis for many countries is not too optimistic. He is hopeful that historical areas of participation in the economy and society at large can be extended, but he argues that the large size of some countries, and the lack of a crisis to rally public spirit, may mean that the reforms he proposes come only spasmodically and could take a long time to fully come to fruition.

The criticisms I have of the book are fairly minor. Boswell does not seem familiar with some areas of the economics of participation that are directly relevant to his arguments, but that is also true of many economists. This omission is not too damaging, given the scope of the book, but his analysis would probably be strengthened by familiarizing himself with some of the literature relating to prewar Yugoslavia. I question some of his suggestions for having extensive "forums" to bring together diverse economic and social interests. Generally, I think his analysis is on target and quite useful at showing some of the specific mechanisms that help keep large diverse economies developing along democratic and humane lines, but I am afraid also of what has been called the "factorial problem" of groups like his suggested forums. In Yugoslavia in the mid 1970s, a type of broadly representative forum was involved in many firm and local government decisions. These groups brought a multiplicity of interests to bear on many micro-decisions, maybe necessarily in many cases, but it has also been argued that these organizations "gummed-up" the decision-making process. I believe the author is aware of this potential problem and is possibly leaving a fuller discussion of the intricacies to another book or authors.

I would highly recommend this book to those who are interested in looking beyond either the market system or total state control of the economy. The range of material covered is broad, but there is an attempt to make specific recommendations. The future of most all economies rests on how the problems addressed in this book are answered, and these answers are especially important to Eastern European countries that are undergoing a dramatic reconstruction.

MARK KLINEDINST University of Southern Mississippi 